\title{
Autochthonous adjunct culture of Limosilactobacillus mucosae CNPC007 improved the techno-functional, physicochemical, and sensory properties of goat milk Greek-style yogurt
}

\author{
Jéssica Lima de Morais, ${ }^{1}$ Estefânia Fernandes Garcia, ${ }^{2}$ Vanessa Bordin Viera, ${ }^{3}$ Edson Douglas Silva Pontes, ${ }^{3}$ \\ Mayara Gabrielly Germano de Araújo, ${ }^{3}$ Rossana Maria Feitosa de Figueirêdo, ${ }^{4}$ Inácia dos Santos Moreira, ${ }^{4}$ \\ Antônio Silvio do Egito, ${ }^{5}$ Karina Maria Olbrich dos Santos, ${ }^{6}$ Juliana Késsia Barbosa Soares, ${ }^{3}$ \\ Rita de Cássia Ramos do Egypto Queiroga, ${ }^{7 *}$ and Maria Elieidy Gomes de Oliveira ${ }^{7} \dagger$ \\ ${ }^{1}$ Post-Graduate Program in Food Science and Technology, Department of Food Engineering, Federal University of Paraíba, 58051-900, \\ João Pessoa, Brazil \\ ${ }^{2}$ Department of Gastronomy, Center for Technology and Regional Development, Federal University of Paraíba, 58058-600, João Pessoa, Brazil \\ ${ }^{3}$ Laboratory of Bromatology, Education and Health Centre, Federal University of Campina Grande, 58175-000, Cuité, Brazil \\ ${ }^{4}$ Laboratory of Storage and Processing of Agricultural Products, Center of Technology and Natural Resources, \\ Federal University of Campina Grande, 58429-900, Campina Grande, Brazil \\ ${ }^{5}$ Embrapa Goats and Sheep, Northeast Regional Center, 58428-095, Campina Grande, Brazil \\ ${ }^{6}$ Brazilian Agricultural Research Corporation (Embrapa), 23020-470, Rio de Janeiro, Brazil \\ ${ }^{7}$ Laboratory of Bromatology, Department of Nutrition, Center of Health Sciences, Federal University of Paraíba, 58051-900, João Pessoa, Brazil
}

\begin{abstract}
We evaluated the performance of Limosilactobacillus mucosae CNPC007 as an autochthonous adjunct culture in the production of goat milk Greek-style yogurt. The techno-functional, physicochemical, and sensory characteristics of the control yogurt (containing only starter culture, CY) and the probiotic yogurt (with the probiotic strain added, PY) were assessed during $28 \mathrm{~d}$ of refrigerated storage. Furthermore, we determined the survival of the strain throughout the gastrointestinal tract under simulated conditions. The PY yogurt had a lower extent of proteolysis index and a higher depth of proteolysis index. These results indicate that the proteolytic enzymes of $L$. mucosae may have a possible action in PY. The PY formulation exhibited viscosity almost 1.5 times as high as $\mathrm{CY}$ over the refrigeration period, probably due to higher production of exopolysaccharides by the probiotic strain, which directly interferes with the microstructure, texture, and viscosity of the product. The PY formulation received higher scores for color, flavor, and global acceptance at $1 \mathrm{~d}$ of storage and higher texture scores at $28 \mathrm{~d}$. The counts of L. mucosae remained high $(>7 \mathrm{log} \mathrm{cfu} / \mathrm{g}$ and $>8.5 \mathrm{log}$ $\mathrm{cfu} / \mathrm{g})$ throughout mouth-ileum digestion and storage, respectively, in PY. The autochthonous adjunct culture of L. mucosae CNPC007 can be used for production of a novel potentially probiotic goat yogurt without
\end{abstract}

Received August 3, 2021.

Accepted November 21, 2021.

*Deceased.

†Corresponding author: elieidynutri@yahoo.com.br negatively affecting the general characteristics of the product quality, adding value associated with maintaining its functional potential.

Key words: fermented goat milk, proteolysis, viscosity, gastrointestinal conditions

\section{INTRODUCTION}

Goat dairy milk products, such as cheese, yogurt, and fermented milk, have been gaining ground among consumers (Jia et al., 2016; de Santis et al., 2019). Despite its technological and market challenges (Ranadheera et al., 2012; Gomes et al., 2013; Yamazi et al., 2013; Ribeiro et al., 2014), goat milk has some nutritional, functional, and technological advantages over cow milk, including greater digestibility and the ability to improve absorption of iron and copper (Silanikove et al., 2010; Mituniewicz-Małek et al., 2014; Clark and Mora García, 2017; Verruck et al., 2019); these characteristics give this food matrix great potential for the elaboration of dairy products, such as yogurt.

Protein-rich yogurts such as Greek-style yogurts are consumed worldwide and exhibit varying compositions and designations, depending on the place of origin (Aryana and Olson, 2017). These yogurts are characterized by 9 to $10 \%$ protein content, creamy texture, and low fat content (Wouters, 2012). Further health benefits result from the addition of probiotic bacteria to dairy products (de Oliveira et al., 2014; Ribeiro et al., 2014; Martins et al., 2018) such as yogurt (Aryana and Olson, 2017), ice cream (Balthazar et al., 2018), and cheese (Silva et al., 2018). The addition of probiotics, live microorganisms that, when ingested in adequate amounts, 
provide benefits to the host, can add greater functional value to goat dairy derivatives (Pal, Dudhrejiya, and Pinto, 2017; de Paula et al., 2020). Probiotics act through several mechanisms of action that culminate in important functions for the consumer's health. Among the properties of these microorganisms, the following stand out: prevention and treatment of gastrointestinal diseases, modulation of the immune system and intestinal microbiota, anticholesterolemic, anti-dyslipidemic and antihypertensive effects, and anticancer, antimicrobial, and antioxidant activities (Fijan, 2014; Terpou et al., 2019).

The genus Lactobacillus contains several potentially probiotic species, including Limosilactobacillus mucosae, a name first proposed in 2000 (Roos et al., 2000). The adhesion of this lactic acid bacteria to gastrointestinal mucus enables efficient intestine colonization. The ability of $L$. mucosae to modulate the intestinal immune system and inhibit pathogenic bacteria (by various mechanisms of action, including the production of organic acids and bacteriocins) renders it a valuable strain in probiotic food development (Bilková et al., 2011). Additionally, the strain's ability to produce exopolysaccharides can be explored in the formulation of dairy products with a richer texture and lower degree of syneresis (London et al., 2015). In particular, the Limosilactobacillus mucosae strain CNPC007 was isolated from goat milk by a group of researchers from the Brazilian Agricultural Research Corporation (Embrapa). This strain brings together a set of probiotic and technological properties previously verified from in vitro tests (de Moraes et al., 2017) and is considered promising for application in functional dairy products (de Moraes et al., 2018).

In this study, we evaluated the effects promoted by the addition of an autochthonous adjunct culture of Limosilactobacillus mucosae CNPC007 on the technofunctional, physicochemical, and sensory characteristics of Greek-style goat yogurt, including the survival of the strain along the simulated gastrointestinal tract.

\section{MATERIALS AND METHODS}

\section{Raw Material and Ingredients}

Milk from Toggenburg goats was provided by a cooperative in Nova Floresta, Paraíba, Brazil. Commercial goat milk powder (Caprilat) and sugar (União, Brazil) were used in the yogurt formulations. The indigenous culture Limosilactobacillus mucosae CNPC007 was obtained from the Collection of Microorganisms of Interest to the Food and Agroenergy Industry of Embrapa Agroindustry Tropical (Fortaleza, Ceará, Brazil), and was cultivated according to de Moraes et al. (2017). The starter culture (Y 472, Clerici-Sacco, Brazil), composed of Streptococcus salivarius ssp. thermophilus and Lactobacillus delbrueckii ssp. bulgaricus, was acquired commercially.

\section{Milk Quality Control}

The titratable acidity, $\mathrm{pH}$, total dry extract, defatted dry extract, protein, fat, and lactose content of goat milk were determined according to the methods of AOAC International (2016). The raw material was assessed for the most probable number (MPN) of total coliforms and thermotolerants (MPN/g), molds and yeast counts in cfu/g, and total count of aerobic mesophilic bacteria $(\mathrm{cfu} / \mathrm{g})$ and detection of absence of Salmonella spp. per $25 \mathrm{~mL}$, considering the criteria established in the current Brazilian legislation (Ministry of Agriculture, Livestock, and Supply, 2000) and standard procedures described elsewhere by the American Public Health Association (APHA, 2015).

\section{Inoculum and Yogurt Preparation}

The inoculum of the probiotic bacteria in milk was prepared in 2 stages. Inoculum 1 was prepared by diluting $0.1 \mathrm{~g}$ of lyophilized L. mucosae CNPC007 in 10 $\mathrm{mL}$ of reconstituted powdered goat milk (Caprilat) in sterile water and incubated for $22 \mathrm{~h}$ (stationary phase) at $37^{\circ} \mathrm{C}$. Final inoculum was prepared in a proportion of $1 / 2$ of inoculum $1+10 \mathrm{~mL}$ of powdered milk reconstituted in sterile water, and incubated for $22 \mathrm{~h}$ at $37^{\circ} \mathrm{C}$, with final counts ranging from 10 to $11 \log \mathrm{cfu} / \mathrm{g}$. The counts were confirmed by using serial dilutions of the inoculum with sterile peptone water at a concentration of $0.1 \mathrm{~g} / 100 \mathrm{~mL}$ (Sigma-Aldrich). Then $10 \mu \mathrm{L}$ of the proper dilutions $\left(10^{-1}\right.$ to $\left.10^{-6}\right)$ were poured onto de Man, Rogosa, and Sharpe agar (Oxoid) and acidified to $\mathrm{pH} 5$ (IDF, 1995) by the microdrop technique. The plates were incubated aerobically at $37^{\circ} \mathrm{C}$ for $48 \mathrm{~h}$. The results were expressed in log $\mathrm{cfu} / \mathrm{g}$.

Yogurts were made from pasteurized goat milk $\left(65^{\circ} \mathrm{C} / 30 \mathrm{~min}\right)$, combined with $10 \%$ sucrose and $10 \%$ powdered goat milk, and subjected to heat treatment $\left(90 \pm 0.5^{\circ} \mathrm{C} / 10 \mathrm{~min}\right)$. After cooling to $40^{\circ} \mathrm{C}$, the milk had a starter culture added (Strep. salivarius ssp. thermophillus and L. delbrueckii ssp. bulgaricus; control yogurt, CY), or a starter culture and $100 \mathrm{~g}$ of final inoculum containing L. mucosae CNPC007 were added (probiotic yogurt, PY). The 2 yogurt formulations (Table 1) were incubated in biochemical oxygen demand at $45 \pm 0.5^{\circ} \mathrm{C}$ for $6 \mathrm{~h}$. Fermentation was terminated at $\mathrm{pH}$ 4.5. After overnight refrigeration, the yogurt was drained in a cloth bag for about 18 to $20 \mathrm{~h}$, 
Table 1. Yogurt formulations

\begin{tabular}{ll}
\hline Code $^{1}$ & Proportions of microorganism \\
\hline CY & $0.4 \mathrm{~g}$ starter culture $/ \mathrm{L}$ of milk \\
PY & $\begin{array}{l}0.4 \mathrm{~g} / \mathrm{L} \text { starter culture }+100 \mathrm{~g} \mathrm{L.} \mathrm{mucosae} \mathrm{final} \\
\text { inoculum/L of milk }\end{array}$ \\
\hline
\end{tabular}

${ }^{1} \mathrm{CY}=$ control yogurt; $\mathrm{PY}=$ probiotic yogurt with added Limosilactobacillus mucosae CNPC007.

as suggested by Şanlıdere Aloğlu and Öner (2013). The yogurt was stored at $4 \pm 0.5^{\circ} \mathrm{C}$ until analysis.

Yogurts were evaluated at times 1, 7, 14, 21, and 28 $\mathrm{d}$ of cold storage $\left(4 \pm 0.5^{\circ} \mathrm{C}\right)$, regarding their technological, physicochemical, microbiological, and sensory characteristics. The protective effect of the food matrix on the survival of lactic acid bacteria in simulated conditions of the gastrointestinal tract (GIT) was assessed at $7 \mathrm{~d}$ of cold storage.

\section{Yogurt Characterization}

Technological Analyses. Apparent viscosity, water retention capacity (WRC), and syneresis of yogurts were assessed in triplicate throughout storage. The susceptibility of yogurt to the separation of water from the clot (syneresis) was determined by draining of $30 \mathrm{~g}$ samples for $5 \mathrm{~h}$ at $4^{\circ} \mathrm{C}$ (Riener et al., 2010). Syneresis (\%) was computed by Equation 1:

$$
\text { Syneresis }=\frac{\text { Whey mass after filtration }}{\text { Fermented milk mass }} \times 100 \text {. }
$$

The WRC was determined by centrifuging yogurt samples under $2,397 \times g, 15 \mathrm{~min}, 10^{\circ} \mathrm{C}$, with a refrigerated centrifuge (model CT-5000R, Cientec; Harte et al., 2003). Apparent viscosity ( $\mathrm{mPa} \cdot \mathrm{s}$ ) of $7.5-\mathrm{mL}$ samples was measured with a Brookfield viscometer (model DV II+Pro) with spindle SC4-21, coupled to a thermostatic bath, at $4^{\circ} \mathrm{C}$ and a speed of $40 \mathrm{rpm}$.

Physicochemical Analyses. Yogurts were submitted, in triplicate, to acidity in lactic acid, $\mathrm{pH}$, total sugars, and proteolysis analyses according to the methods of the Association of Official Analytical Chemists (AOAC, 2016). The following tests were performed: $\mathrm{pH}$ with a digital $\mathrm{pH}$ meter (Q400, Quimis); acidity in lactic acid by titration; and total sugars by Fehling reduction. The extent of proteolysis index and the depth of proteolysis index were determined by the micro-Kjeldahl method (AOAC, 2016) and Equations [2] and [3] (Andreatta et al., 2007):

$$
\mathrm{EPI}=\frac{\mathrm{SN} \text { at } \mathrm{pH} 4.6}{\mathrm{TN}} \times 100
$$

$$
\mathrm{DPI}=\frac{\mathrm{SN} \text { in } \mathrm{TCA}}{\mathrm{TN}} \times 100,
$$

where EPI is the extent of proteolysis index (\%); DPI is the depth of proteolysis index (\%); SN represents the soluble nitrogen; TN, the total nitrogen; and TCA represents trichloroacetic acid.

\section{Sanitary Quality and Lactic Acid Bacteria Viability}

Quality control tests comprised the Escherichia coli count, as well as the total mold and yeast counts in colony-forming units per gram (cfu/g), and detection of absence of Salmonella spp. per 25 g (APHA, 2015; Brazil, National Health Surveillance Agency, 2019). The lactic acid bacteria viability included the counts of Strep. salivarius ssp. thermophilus (APHA, 2015), Limosilactobacillus mucosae CNPC007 (London et al., 2015), and Lactobacillus ssp. bulgaricus (Lima et al., 2009).

\section{Survival of Probiotic Bacteria Under Simulated Gastrointestinal Conditions}

The survival of lactic acid bacteria in yogurts stored at $4 \pm 0.5^{\circ} \mathrm{C}$ for $7 \mathrm{~d}$ was assessed during GIT simulated digestion, according to de Oliveira et al. (2014) and Madureira et al. (2011).

Inoculation of Fermented Milk Matrices. For PY yogurt formulation, 5 samples labeled C1, C2, C3, $\mathrm{S} 1$, and S2 were produced: $\mathrm{C} 1$ and $\mathrm{C} 2$ are duplicate control yogurts, which were inoculated with the tested probiotic strain but not exposed to simulated gastrointestinal conditions; C3 refers to the control yogurt inoculated with probiotic strain and exposed to simulated gastrointestinal conditions (used in $\mathrm{pH}$ adjustments over the stages of simulated digestion); S1 and S2 are yogurts inoculated and exposed to simulated gastrointestinal conditions. All samples were prepared in sterile $50-\mathrm{mL}$ vials, containing $25 \mathrm{~g}$ of yogurt.

Simulation of Gastrointestinal Conditions. The gastrointestinal tract was simulated as per the conditions described in Table 2 and as follows:

- Stage 1 (Before simulation): Samples were evaluated before simulation of ingestion.

- Stage 2 (Mouth): Chewing was simulated using a saliva solution prepared with $100 \mathrm{U} / \mathrm{mL}$ of $\alpha$-amylase (Sigma-Aldrich) diluted in $1 \mathrm{mM} \mathrm{CaCl} 2$ solution. Saliva solution was added to $25 \mathrm{-g}$ samples at a rate of $0.6 \mathrm{~mL} / \mathrm{min}$ for $2 \mathrm{~min}$. The $\mathrm{pH}$ was adjusted to 6.9 using $0.1 \mathrm{M} \mathrm{NaHCO}_{3}$ solution.

- Stages 3 to 8 (Esophagus-stomach): Pepsin solution was added at a rate of $0.05 \mathrm{~mL} / \mathrm{mL}$ for $90 \mathrm{~min}$. 
Table 2. Processing conditions used in simulated digestion

\begin{tabular}{|c|c|c|c|c|c|}
\hline Stage & Compartment & Condition & $\begin{array}{l}\text { Stirring speed } \\
\quad(\mathrm{rpm})\end{array}$ & $\begin{array}{l}\text { Final } \\
\mathrm{pH}\end{array}$ & $\begin{array}{l}\text { Exposure } \\
\text { time (min) }\end{array}$ \\
\hline 1 & Before mouth & - & - & - & - \\
\hline 2 & Mouth & Saliva solution & 200 & 6.9 & 2 \\
\hline 4 & & & & 4.6 & 10 \\
\hline 5 & & & & 3.8 & 10 \\
\hline 6 & & & & 2.8 & 20 \\
\hline 9 & Duodenum & Intestinal solution (pancreatin + bile salts) & 45 & 5.0 & 30 \\
\hline 10 & Ileum & & 45 & 6.5 & 60 \\
\hline
\end{tabular}

Pepsin solution (Sigma-Aldrich) was prepared in $\mathrm{HCl}$ at $0.1 \mathrm{~N}$ in a ratio of $25 \mathrm{mg} / \mathrm{mL}$ (Aura, 2005). The $\mathrm{pH}$ of each stage was adjusted according to Table 2, using $1 \mathrm{M} \mathrm{HCl}$ solution.

- Stage 9 (Duodenum): The intestinal solution was added to the samples at a rate of $0.25 \mathrm{~mL} / \mathrm{mL}$ (Laurent et al., 2007). Such solution was prepared using $2 \mathrm{~g} / \mathrm{L}$ pancreatin and $12 \mathrm{~g} / \mathrm{L}$ bile salts (Sigma-Aldrich), diluted in $0.1 \mathrm{M} \mathrm{NaHCO}_{3}$ solution. The $\mathrm{pH}$ adjustment was made with a $0.1 \mathrm{M}$ $\mathrm{NaHCO}_{3}$ solution.

- Stage 10 (Ileum): A $0.1 \mathrm{M} \mathrm{NaHCO}_{3}$ solution was used to adjust $\mathrm{pH}$ to 6.5 .

All enzymatic solutions were prepared in sterile filtered vials using a $0.22-\mu \mathrm{m}$ filter membrane (Milipore). After sterilization, all solutions were kept in an ice bath throughout the simulation period. A $37^{\circ} \mathrm{C}$ incubation chamber with mechanical stirring (TE-424 TECNAL Orbital Shaker, Incubadora) was used to simulate both body temperature and intestinal peristaltic movements similar to those of each digestive compartment. For each stage of simulation of the GIT, the viable cell counts of lactic acid bacteria added to yogurts were determined by preparation and sowing of decimal serial dilutions with sterilized peptone water $(0.1 \mathrm{~g} / 100 \mathrm{~mL}$, Sigma-Aldrich; London et al., 2015).

\section{Sensory Analysis}

Microbiological tests preceded the sensory analysis to ensure the yogurts met legislated sanitary standards (Brazil, National Health Surveillance Agency, 2019). The authors declare that the present study was carried out in accordance with the Research Ethics Committee of the Health Sciences Center of the Federal University of Paraíba-CEP/CSS (João Pessoa, Brazil). The approval number is CAAE 02226912.0.0000.5188, and written consent was obtained. Informed written consent was obtained from willing participants before the start of the study.
The participants filled out the informed consent form before the sensory tests. Consumers were recruited through personal contact and invitations via social media, and individuals who were healthy, consumed fermented dairy products, had already consumed goat milk or goat milk dairy products, and had available time for the sensory analyses were selected. One hundred regular consumers of fermented dairy products ( $45 \%$ men, $55 \%$ women; aged 18-45 yr; mean age 22 yr) participated in the sensory acceptance test. All of the participants consumed yogurts, fermented milks, or fermented whey beverages at least 3 times a week.

The sensory attributes evaluated included appearance, color, aroma, flavor, texture, and overall acceptance of the yogurt formulations. Ten-gram samples at $4 \pm 0.5^{\circ} \mathrm{C}$ were presented to the panelists in $50-\mathrm{mL}$ white plastic cups labeled with 3 -digit numbers following a monadic sequential order. Consumers evaluated the sensory acceptance on a 9-point hedonic scale $(1=$ disliked very much; $5=$ neither liked nor disliked; $9=$ liked very much; García-Gómez et al., 2019). A glass of water and biscuits were provided for cleansing the palate during evaluation of the different yogurt formulations. Yogurts were considered accepted when they received an average score of 5.0 or higher.

\section{Statistical Analysis}

Data were submitted to Student's $t$-test or ANOVA followed by Tukey's test with significance declared at $P$ $\leq 0.05$, using Statistica software, version 13 (StatSoft). Graphs were plotted using Matlab, version R2019b.

\section{RESULTS AND DISCUSSION}

\section{Goat Milk Quality Control}

Microbiological analyses revealed total and thermotolerant coliform counts $<3 \mathrm{MPN} / \mathrm{mL}$ and mold and yeast counts $<1 \mathrm{cfu} / \mathrm{mL}$, in addition to absence of $\mathrm{Sal}$ - 
Table 3. Goat milk physicochemical properties

\begin{tabular}{lrl}
\hline Property $^{1}$ & Mean $\pm \mathrm{SD}$ & Literature reference \\
\hline $\mathrm{pH}$ & $6.75 \pm 0.00$ & $6.49 \pm 0.05^{2}$ and $6.75 \pm 0.00^{3}$ \\
Titratable acidity (g of lactic acid/100 g) & $0.11 \pm 0.01$ & $0.12 \pm 0.02^{2}$ and $0.13 \pm 0.01^{3}$ \\
$\mathrm{TDE}(\mathrm{g} / 100 \mathrm{~g})$ & $13.55 \pm 0.20$ & $13.56 \pm 0.03^{2}$ and $13.18 \pm 1.28^{4}$ \\
$\mathrm{DDE}(\mathrm{g} / 100 \mathrm{~g})$ & $10.40 \pm 0.10$ & $11.24 \pm 0.02^{2}$ \\
Protein $(\mathrm{g} / 100 \mathrm{~g})$ & $3.99 \pm 0.02$ & $4.67 \pm 0.15,{ }^{4} 3.59 \pm 0.09,^{5}$ and $3.57 \pm 0.07^{3}$ \\
Fat $(\mathrm{g} / 100 \mathrm{~g})$ & $3.15 \pm 0.02$ & $6.82 \pm 0.04,{ }^{2} 5.20 \pm 0.05,{ }^{4} 3.51 \pm 0.14,^{5}$ and $3.01 \pm 0.01^{3}$ \\
Lactose $(\mathrm{g} / 100 \mathrm{~g})$ & $3.82 \pm 0.00$ & $3.17 \pm 0.42^{5}$ and $4.30 \pm 0.04^{3}$ \\
\hline
\end{tabular}

${ }^{1} \mathrm{TDE}=$ total dry extract; DDE $=$ defatted dry extract.

${ }^{2}$ Rafiq et al. (2016).

${ }^{3}$ Machado et al. (2017).

${ }^{4}$ Vyhmeister et al. (2019).

${ }^{5}$ Fabersani et al. (2018).

monella spp. and Listeria monocytogenes, confirming the goat milk as being suitable for human consumption and for use as a raw material for preparing yogurts. The milk presented acidity in lactic acid $( \pm$ SD) of 0.11 $\pm 0.01 \mathrm{~g} / 100 \mathrm{~g} ; \mathrm{pH}$ of $6.75 \pm 0.00$; total solids 13.55 $\pm 0.20 \mathrm{~g} / 100 \mathrm{~g}$; protein $3.99 \pm 0.02 \mathrm{~g} / 100 \mathrm{~g}$; fat 3.15 $\pm 0.02 \mathrm{~g} / 100 \mathrm{~g}$; lactose $3.82 \pm 0.00 \mathrm{~g} / 100 \mathrm{~g}$; and fixed mineral residue $0.70 \pm 0.01$ (Table 3). Most of these results were in agreement with studies by other authors (Rafiq et al., 2016; Machado et al., 2017; Fabersani et al., 2018; Vyhmeister et al., 2019).

\section{Technological and Physicochemical Characteristics of Yogurt}

We observed an increase in acidity and consequent reduction in the $\mathrm{pH}$ of the 2 samples throughout storage (Figure 1), which is explained by the continued production of acids by lactic acid bacteria (from the starter culture or probiotic strain, or both). The formulation containing L. mucosae (PY) exhibited lower total sugar content than the CY sample after $7 \mathrm{~d}$ of storage onward. This behavior was possibly due to the action of starter bacteria (Strep. salivarius ssp. thermophilus and L. delbrueckii ssp. bulgaricus) in coculture with the autochthonous bacterium L. mucosae CNPC007 present in the PY formulation, which may have contributed to a higher consumption of sugar after $7 \mathrm{~d}$ of storage. Zhang et al. (2020), in a study on yogurt making by co-cultivation of Lactobacillus plantarum WCFS1 with yogurt starter cultures, also observed this same behavior for the formulation of yogurt in coculture with L. plantarum, indicating higher consumption of sugars when other groups of microorganisms are added in addition to the starter culture.

The depth of proteolysis index (Figure 2) shows that the action of microbial enzymes on the yogurt proteins increased throughout storage in both formulations $(P$ $\leq 0.05$ ). The extent of proteolysis index refers to the natural proteinases of milk and the action of coagulating agents added in the processing of dairy products, which degrade proteins in peptides of high molecular weight (Narimatsu et al., 2003). In this study, we did not use coagulating agents in the processing of yogurts. As the extent of proteolysis index increased in $\mathrm{CY}$ and decreased in PY, we concluded that the proteolytic action of microbial enzymes exceeded the activity of milk proteinases in the formulation with L. mucosae CNPC007.

Syneresis increased by about $1 \%$ over storage time in both samples $(P \leq 0.05)$, reaching a final value of around $25 \%$ (Figure 2). According to Ramirez-Santiago et al. (2010), syneresis in yogurts occurs due to rearrangements in the casein network, which promote the expulsion of serum. Syneresis values up to $39 \%$ are considered satisfactory (Aportela-Palacios et al., 2005). However, WRC increased up to $21 \mathrm{~d}$ for PY $(P \leq 0.05)$ and dropped dramatically at $28 \mathrm{~d}$ in both samples, especially in PY (Figure 2). Exopolysaccharides commonly produced by $L$. mucosae may explain the highest WRC value in $21 \mathrm{~d}$ of storage (Figure 2; London et al., 2015). However, we conclude that, after a certain period, the breakdown of the yogurts' protein network promoted by lactic acid bacteria from the starter culture and by L. mucosae surpassed the production of exopolysaccharides, culminating in a reduction in WRC and increased syneresis (Machado et al., 2017).

The apparent viscosity of yogurt decreased after $28 \mathrm{~d}$ of storage $(P \leq 0.05)$ only in the PY formulation (Table 4). However, PY exhibited viscosity $(\mathrm{mPa} \cdot \mathrm{s})$ almost 1.5 times as high as CY over $28 \mathrm{~d}(P \leq 0.05)$, which can be explained by the effects of exopolysaccharides produced by the probiotic strain on the microstructure, texture, and viscosity of yogurt. Yang et al. (2014) and London et al. (2015) observed the same effect in yogurt with added lactic acid bacteria, including L. mucosae. Ac- 
cording to those authors, exopolysaccharides contribute to the formation of a microstructure with denser pores and, therefore, confer higher viscosity to yogurts. For this reason, London et al. (2015) recommend the use of exopolysaccharide-producing strains of $L$. mucosae to confer a richer texture in low-fat yogurts, such as Greek-style yogurt.

Food-grade polysaccharides from lactic acid bacteria are well known as nontoxic, biodegradable, and ecological ingredients that act as natural thickeners, emulsifiers, stabilizers, binders, gelifiers, coagulants, and suspension agents in food and cosmetic products (Jindal and Kattar, 2018). However, the texture of food products generally depends on both the fermentation bacteria and the process parameters. Some lactic acid bacteria can improve texture by producing metabolites in the medium or hydrolyzing fibers added to the food during processing (Escobar et al., 2012). In addition, bacterial exopolysaccharides may offer several human health benefits, such as immunomodulatory, antitumor, and antioxidant activities, blood cholesterol reducing ability, and prebiotic properties (Yildiz and Karatas, 2018).

\section{Microbiological Characterization of Yogurt and Survival of L. mucosae CNPC007 Under Simulated Gastrointestinal Conditions}

The results of hygienic sanitary microbiological analysis revealed that all prepared goat yogurt formulations were suitable for human consumption throughout the assessed refrigerated storage period, because the counts for E. coli, molds, and yeasts and absence of Salmonella spp. were in accordance with the criteria recommended by current Brazilian legislation (Brazil, National Health Surveillance Agency, 2019), indicating good manufacturing practices.

Probiotic properties are attributed to some L. mucosae strains due to their adhesion to the intestinal mucosa, resistance to passage through the gastrointestinal tract, immunomodulatory capacity, and production of exopolysaccharides and bacteriocins (London et al., 2015; de Moraes et al., 2018). Therefore, tests of viability during storage (Figure 3) and L. mucosae survival of digestion (Figure 4) were performed to evaluate the ability of Greek-style goat yogurt to carry this probiotic strain.

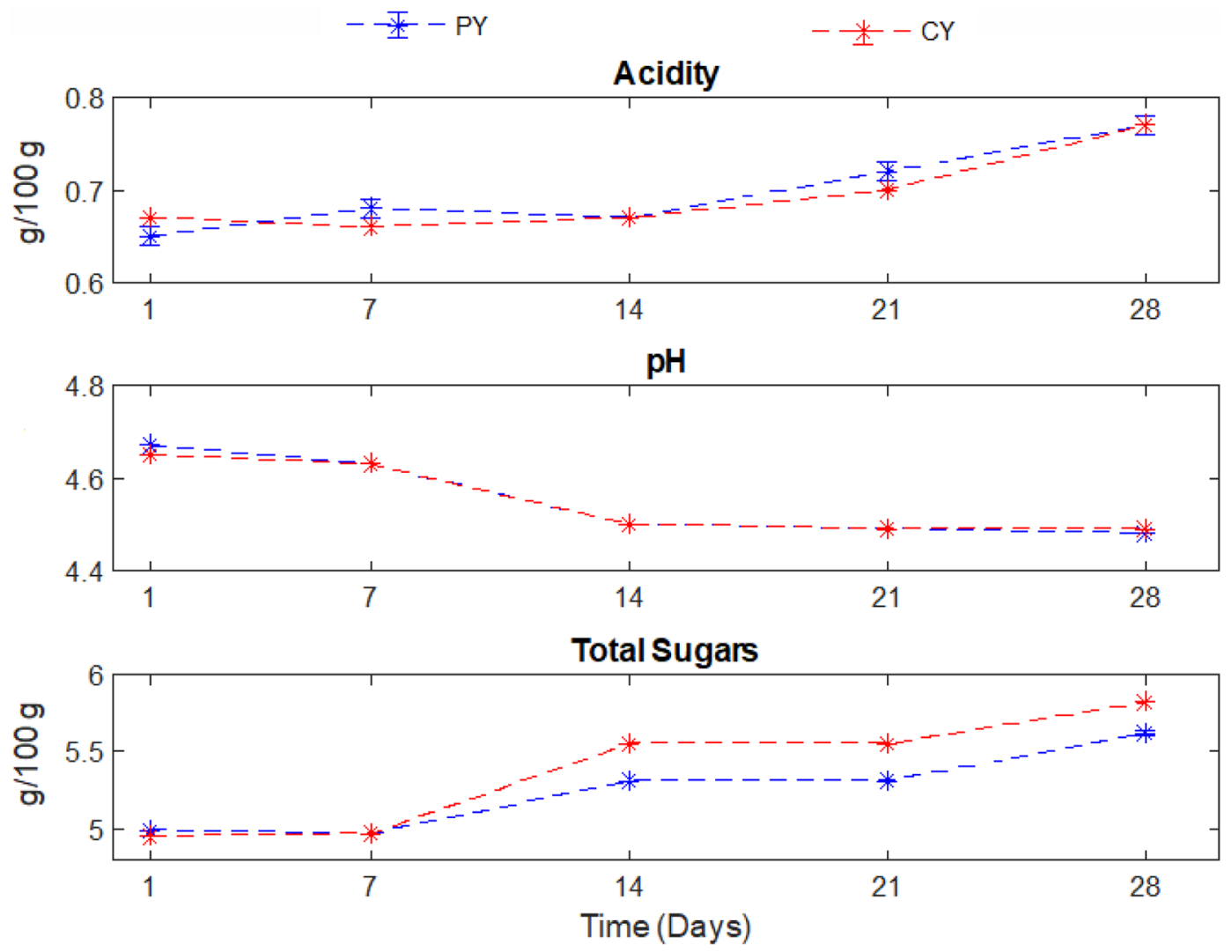

Figure 1. Acidity in lactic acid (g/100 g), $\mathrm{pH}$, and total sugars (g/100 g) of control yogurt (CY, red) and probiotic yogurt with added Limosilactobacillus mucosae CNPC007 (PY, blue) over 28 d of storage. Error bars indicate SD. 
Table 4. Apparent viscosity $(\mathrm{mPa} \cdot \mathrm{s})$ of yogurt over storage

\begin{tabular}{|c|c|c|}
\hline \multirow{2}{*}{$\begin{array}{l}\text { Storage } \\
\text { time (d) }\end{array}$} & \multicolumn{2}{|c|}{ Formulation $^{1}$} \\
\hline & $\mathrm{CY}$ & PY \\
\hline $\begin{array}{l}1 \\
7 \\
14 \\
21 \\
28\end{array}$ & $\begin{aligned} 1,390.33 & \pm 54.65^{\mathrm{A}, \mathrm{b}} \\
1,019.16 & \pm 105.01^{\mathrm{AB}, \mathrm{b}} \\
958.17 & \pm 115.96^{\mathrm{AB}, \mathrm{b}} \\
853.46 & \pm 66.35^{\mathrm{B}, \mathrm{b}} \\
1,265.00 & \pm 349.68^{\mathrm{AB}, \mathrm{b}}\end{aligned}$ & $\begin{array}{l}2,399.00 \pm 55.15^{\mathrm{A}, \mathrm{a}} \\
1,574.00 \pm 26.96^{\mathrm{B,a}} \\
1,426.00 \pm 121.75^{\mathrm{B}, \mathrm{a}} \\
1,626.00 \pm 76.21^{\mathrm{B}, \mathrm{a}} \\
1,718.25 \pm 150.86^{\mathrm{B,a}}\end{array}$ \\
\hline
\end{tabular}

${ }^{\mathrm{a}, \mathrm{b}}$ Means $\pm \mathrm{SD}$ with different lowercase letters in the same row represent differences between formulations according to Student's $t$-test $(P \leq 0.05)$.

${ }^{\mathrm{A}, \mathrm{B}}$ Means $\pm \mathrm{SD}$ with different uppercase letters in the same column represent differences between storage times according to Tukey test $(P \leq 0.05)$.

${ }^{1} \mathrm{CY}=$ control yogurt; $\mathrm{PY}=$ probiotic yogurt with added Limosilactobacillus mucosae CNPC007.

The counts of L. bulgaricus ssp. delbrueckii (Figure 3) increased by about $0.5 \mathrm{log} \mathrm{cfu} / \mathrm{g}$ over the $28 \mathrm{~d}$ of storage. The PY and CY formulations showed an increase $(P \leq 0.05)$ from $8.59 \pm 0.02 \log \mathrm{cfu} / \mathrm{g}$ to $8.99 \pm 0.01$ $\log \mathrm{cfu} / \mathrm{g}$ and $8.65 \pm 0.08 \mathrm{log} \mathrm{cfu} / \mathrm{g}$ to $9.00 \pm 0.01$ $\log \mathrm{cfu} / \mathrm{g}$, respectively. Counts of Strep. salivarius ssp. thermophilus (Figure 3) decreased in both formulations
$(P \leq 0.05)$, with a particular drop in the CY sample. The reduction in Strep. thermophilus was about $0.5 \mathrm{log}$ $\mathrm{cfu} / \mathrm{g}$ in PY $(9.38 \pm 0.11 \mathrm{log} \mathrm{cfu} / \mathrm{g}$ to $8.98 \pm 0.02 \mathrm{log}$ $\mathrm{cfu} / \mathrm{g})$ and almost $1.5 \mathrm{log} \mathrm{cfu} / \mathrm{g}$ in CY $(9.38 \pm 0.05 \mathrm{log}$ $\mathrm{cfu} / \mathrm{g}$ to $8.06 \pm 0.05 \mathrm{log} \mathrm{cfu} / \mathrm{g})$. This type of behavior is expected in the yogurt fermentation process, in which strains of Strep. salivarius ssp. thermophilus and L. delbrueckii ssp. bulgaricus show synergistic interactions (protocooperation). Lactobacillus delbrueckii ssp. bulgaricus initially grows more slowly than Strep. thermophilus but remains viable for a much longer time. Streptococcus salivarius ssp. thermophilus, in turn, grows more quickly at the beginning of the process, when the $\mathrm{pH}$ of the milk is close to neutral; but, toward the end, due to greater production of lactic acid and sensitivity to acidity, it is surpassed by $L$. bulgaricus. Thus, at the end of the process, a much larger number of $L$. bulgaricus than Strep. thermophilus is found (McKevith and Shortt, 2003; Narvhus and Abrahamsen, 2021).

The yogurt containing L. mucosae CNPC007 (Figure 3) showed a reduction in the count of this probiotic strain $(P \leq 0.05)$, from $9.53 \pm 0.04 \mathrm{log} \mathrm{cfu} / \mathrm{g}$ to 8.96 $\pm 0.01 \mathrm{log} \mathrm{cfu} / \mathrm{g}$. Possibly, competition for substrate between $L$. bulgaricus and L. mucosae further contrib-

$$
-- \text { - PY }
$$$$
- \text { 米 }-\mathrm{CY}
$$
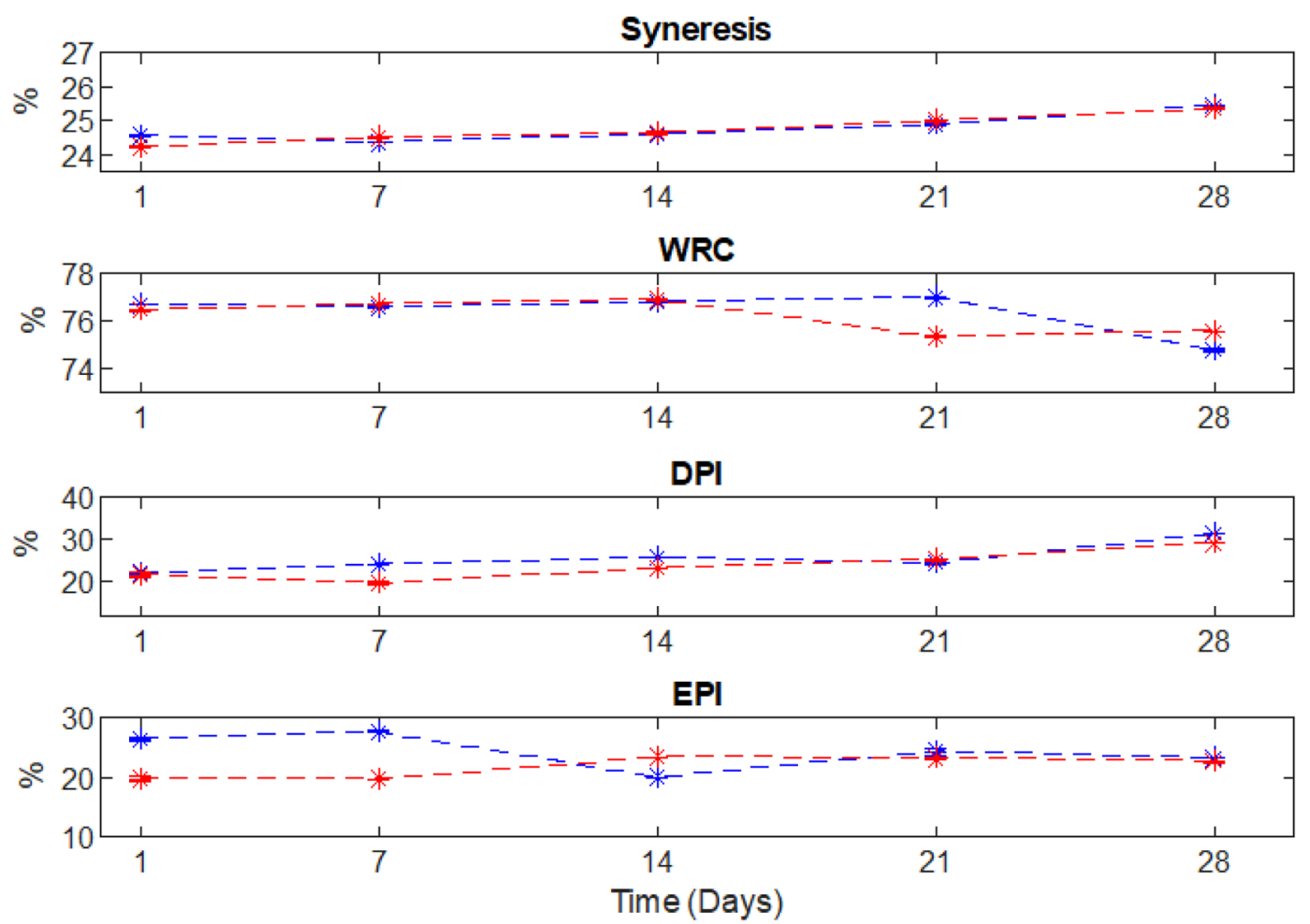

Figure 2. Syneresis (\%), water retention capacity (WRC, \%), depth of proteolysis index (DPI, \%), and extent of proteolysis index (EPI, \%) of control yogurt (CY, red) and probiotic yogurt with added Limosilactobacillus mucosae CNPC007 (PY, blue) over 28 d of storage. Error bars indicate SD. 
uted to the reduction of the probiotic strain during storage. In parallel with the antagonistic effect between L. bulgaricus and the probiotic strain, synthesis of bacteriocins and organic acids may have occurred (London et al., 2015; de Moraes et al., 2018), in addition to release of microbial metabolites. Even so, over the entire storage period, the PY formulation showed probiotic bacteria counts much higher than the minimum recommended to produce beneficial health effects (6.0 to 7.0 log cfu in $100 \mathrm{~g}$; Terpou et al., 2019).

Figure 4 illustrates the survival of L. mucosae CNPC007 along the simulated gastrointestinal tract. The counts of the probiotic strain in the sample that was not exposed to in vitro digestion are also shown. As expected, greater stability and higher counts $(P \leq$ $0.05)$ were observed in the sample that was not exposed to simulated digestion. The greatest drop in L. mucosae CNPC007 counts occurred in stomach conditions $(P \leq$ 0.05). Upon reaching the duodenum, at about $90 \mathrm{~min}$ of exposure, a considerable drop occurred in the number of viable cells compared with the counts found during mouth digestion (more than $2 \mathrm{log} \mathrm{cfu} / \mathrm{g}$ ), with counts remaining stable until reaching the ileum. At the end of the 182 min of simulated digestion, the yogurt showed sufficient viability to be considered a probiotic product, with an average viable cell population of $L$. mucosae around 7 log cfu/g (Terpou et al., 2019). This behavior indicates a possible protective effect of the food matrix on the survival of L. mucosae CNPC007, contributing to the product's probiotic effects.

\section{Sensory Acceptance Test}

Both yogurt formulation samples received the same sensory acceptance scores in terms of appearance and aroma $(P>0.05)$, both at the beginning and at the end of storage (Table 5). On the first day of storage, PY and CY received the same score for texture $(P>0.05)$. However, PY received the highest scores for color, flavor, and overall acceptability both at the beginning and at the end of storage $(P \leq 0.05)$, demonstrating that the L. mucosae strain potentiated better sensory acceptance of these attributes evaluated in this formulation. The PY formulation also received higher texture scores at $28 \mathrm{~d}(P \leq 0.05)$, corroborating the viscosity results that this formulation had higher

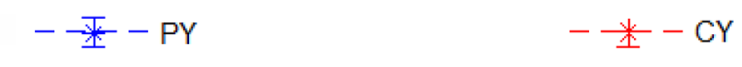

L. bulgaricus

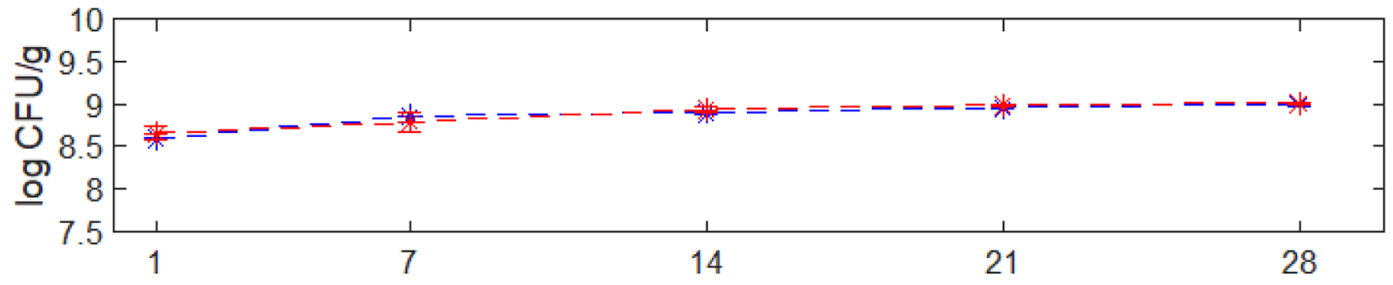

S. thermophilus
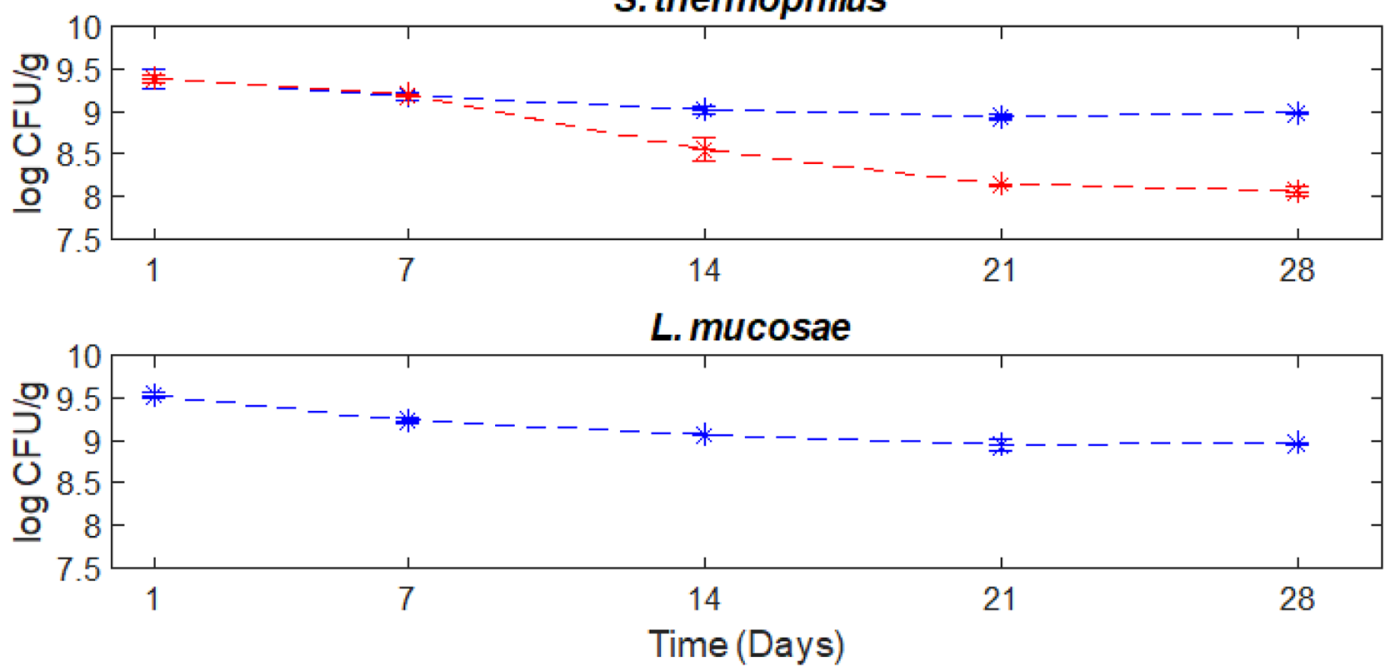

Figure 3. Viability of lactic acid bacteria (Lactobacillus delbrueckii ssp. bulgaricus, Streptococcus salivarius ssp. thermophilus, and Limosilactobacillus mucosae CNPC007) in control yogurt (CY, red) and probiotic yogurt with added Limosilactobacillus mucosae CNPC007 (PY, blue) over 28 d of storage. Error bars indicate SD. 
viscosity than $\mathrm{CY}$, which may have led to higher texture scores.

According to the panelists, the 2 samples' appearance and color remained unchanged over time $(P>$ 0.05). However, the aroma, flavor, and overall acceptability improved over storage in both samples $(P \leq$ 0.05). The PY formulation received scores between 7 to 9 throughout storage ("liked it moderately" to "liked it extremely"). In other words, the addition of L. mucosae did not cause negative effects on the general evaluation of yogurt and provided an increase in the acceptance of the product.

\section{CONCLUSIONS}

The addition of the L. mucosae strain CNPC007 provided a more viscous and creamier Greek-style yogurt than the control. In addition, the formulation with added L. mucosae showed higher sensory acceptance scores for color, flavor, texture, and global assessment. The viability and GIT tests indicated that the probiotic yogurt developed is an efficient vehicle of probiotic bacteria for human consumption, as lactic acid bacteria counts remained high ( $>7 \log \mathrm{cfu} / \mathrm{g})$ throughout storage and simulated gastrointestinal conditions, respectively. These results indicate a great technological potential of L. mucosae CNPC007 in the development of functional goat milk yogurts.

\section{ACKNOWLEDGMENTS}

Sadly, Rita Queiroga (Federal University of Paraíba) died as a consequence of COVID-19 shortly before publication of this article, after 30 years of dedicated

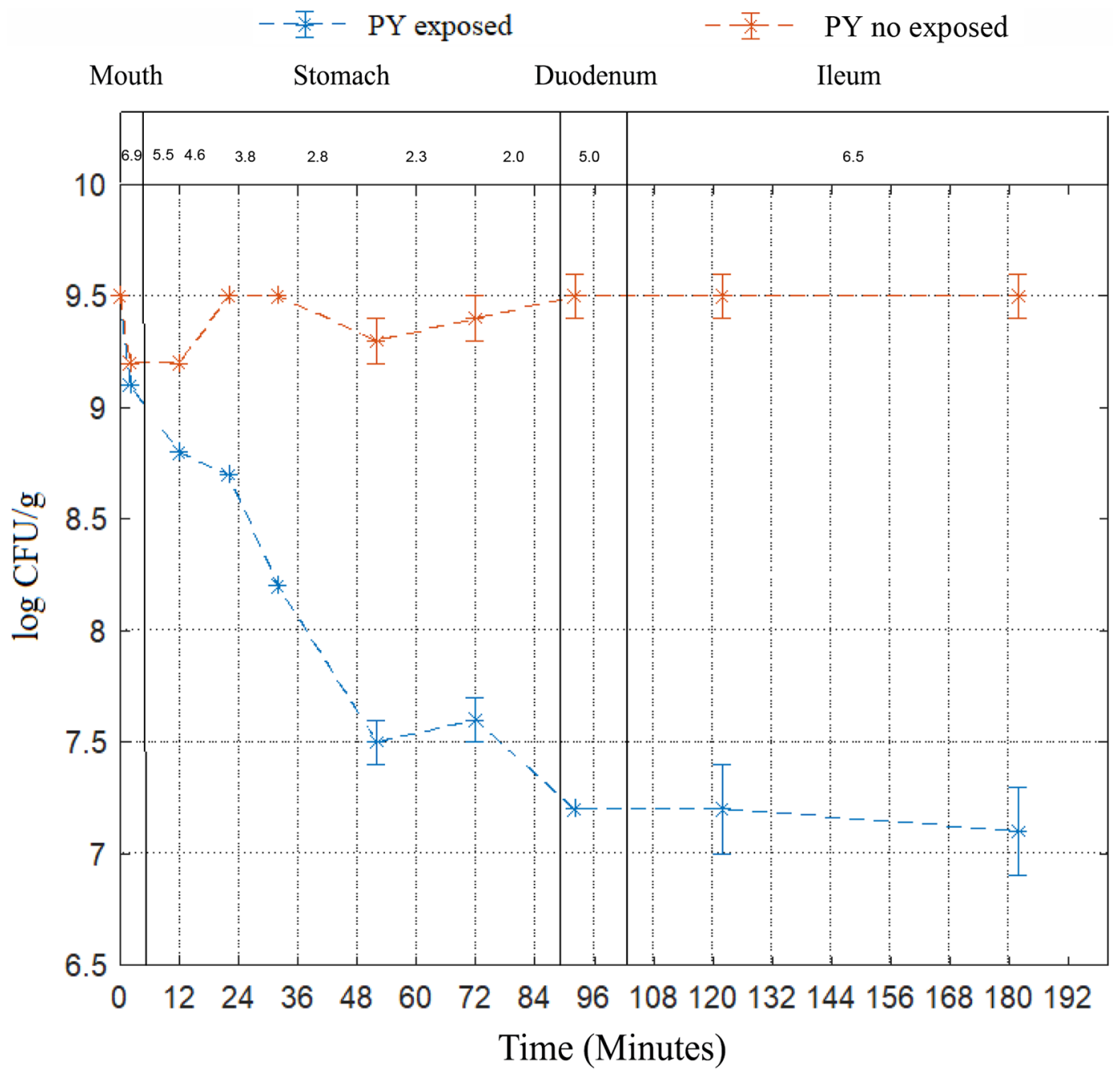

Figure 4. Viable cell counts of Lactobacillus mucosae CNPC007 in Greek-style goat yogurt when exposed (blue) and not exposed (red) to simulated digestion. The $\mathrm{pH}$ values in each digestion stage are shown at the top of the graph. PY = probiotic yogurt with added $L$. mucosae CNPC007. Error bars indicate SD. 
Table 5. Sensory acceptance of yogurts at beginning and end of storage $(\mathrm{n}=100)$

\begin{tabular}{|c|c|c|c|}
\hline \multirow[b]{2}{*}{ Property } & \multirow{2}{*}{$\begin{array}{l}\text { Day of } \\
\text { storage }\end{array}$} & \multicolumn{2}{|c|}{ Formulation $^{1}$} \\
\hline & & $\mathrm{CY}$ & PY \\
\hline \multirow[t]{2}{*}{ Appearance } & 1 & $7.71 \pm 0.59^{\mathrm{a}, \mathrm{A}}$ & $7.72 \pm 0.61^{\mathrm{a}, \mathrm{A}}$ \\
\hline & 28 & $7.69 \pm 0.60^{\mathrm{a}, \mathrm{A}}$ & $7.81 \pm 0.53^{\mathrm{a}, \mathrm{A}}$ \\
\hline \multirow[t]{2}{*}{ Color } & 1 & $7.88 \pm 0.50^{\mathrm{a}, \mathrm{B}}$ & $8.08 \pm 0.60^{\mathrm{a}, \mathrm{A}}$ \\
\hline & 28 & $7.90 \pm 0.48^{\mathrm{a}, \mathrm{B}}$ & $8.16 \pm 0.51^{\mathrm{a}, \mathrm{A}}$ \\
\hline \multirow[t]{2}{*}{ Aroma } & 1 & $7.20 \pm 0.85^{\mathrm{b}, \mathrm{A}}$ & $7.20 \pm 0.70^{\mathrm{b}, \mathrm{A}}$ \\
\hline & 28 & $7.61 \pm 0.57^{\mathrm{a}, \mathrm{A}}$ & $7.50 \pm 0.66^{\mathrm{a}, \mathrm{A}}$ \\
\hline \multirow{2}{*}{ Flavor } & 1 & $6.56 \pm 0.78^{\mathrm{b}, \mathrm{B}}$ & $7.51 \pm 0.54^{\mathrm{a}, \mathrm{A}}$ \\
\hline & 28 & $6.98 \pm 0.91^{\mathrm{a}, \mathrm{B}}$ & $7.43 \pm 0.54^{\mathrm{a}, \mathrm{A}}$ \\
\hline \multirow{2}{*}{ Texture } & 1 & $7.81 \pm 0.53^{\mathrm{a}, \mathrm{A}}$ & $7.93 \pm 0.97^{\mathrm{a}, \mathrm{A}}$ \\
\hline & 28 & $7.43 \pm 0.83^{\mathrm{b}, \mathrm{B}}$ & $8.03 \pm 0.56^{\mathrm{a}, \mathrm{A}}$ \\
\hline \multirow{2}{*}{ Overall acceptance } & 1 & $6.84 \pm 0.83^{\mathrm{b}, \mathrm{B}}$ & $7.87 \pm 0.65^{\mathrm{b}, \mathrm{A}}$ \\
\hline & 28 & $7.06 \pm 0.34^{\mathrm{a}, \mathrm{B}}$ & $8.04 \pm 0.45^{\mathrm{a}, \mathrm{A}}$ \\
\hline
\end{tabular}

$\overline{\mathrm{a}, \mathrm{b}}$ Comparisons between storage times for the same formulation. Values in the same column marked with different lowercase letters differed according to Student's $t$-test $(P \leq 0.05)$ for a given property.

${ }^{\mathrm{A}, \mathrm{B}}$ Comparisons between formulations at times 1 and $28 \mathrm{~d}$ of storage. Values in the same row marked with different uppercase letters differed according to Student's $t$-test $(P \leq 0.05)$ for a given property.

${ }^{1} \mathrm{CY}=$ control yogurt; $\mathrm{PY}=$ probiotic yogurt with added Limosilactobacillus mucosae CNPC007.

research focused on dairy products from goats and, latterly, donkey milk and cactus. This study received no external funding. The authors have not stated any conflicts of interest.

\section{REFERENCES}

Andreatta, E., A. M. Fernandes, M. V. dos Santos, C. G. de Lima, C. Mussarelli, M. C. Marques, and C. A. F. de Oliveira. 2007. Effects of milk somatic cell count on physical and chemical characteristics of mozzarella cheese. Aust. J. Dairy Technol. 62:166-170.

AOAC International. 2016. Official Methods of Analysis. 20th ed. AOAC International.

APHA (American Public Health Association). 2015. Compendium of Methods for the Microbiological Examination of Foods. 15th ed. American Public Health Association. https://doi.org/10.2105/ MBEF.0222

Aportela-Palacios, A., M. E. Sosa-Morales, and J. F. Vélez-Ruiz. 2005. Rheological and physicochemical behavior of fortified yogurt, with fiber and calcium. J. Texture Stud. 36:333-349. https://doi.org/10 $.1111 /$ j.1745-4603.2005.00020.x.

Aryana, K. J., and D. W. Olson. 2017. A 100-year review: Yogurt and other cultured dairy products. J. Dairy Sci. 100:9987-10013. https: //doi.org/10.3168/jds.2017-12981.

Aura, A. M. 2005. In vitro digestion models for dietary phenolic compounds. PhD Thesis. Department of Chemical Technology, Helsinki University of Technology.

Balthazar, C. F., H. L. A. Silva, E. A. Esmerino, R. S. Rocha, J. Moraes, M. A. V. Carmo, L. Azevedo, I. Camps, Y. K. D. Abud, C. Sant'Anna, R. M. Franco, M. Q. Freitas, M. C. Silva, R. S. L. Racies, G. B. Escher, D. Granato, C. S. Ranadheera, F. Nazzaro, and A. G. Cruz. 2018. The addition of inulin and Lactobacillus casei 01 in sheep milk ice cream. Food Chem. 246:464-472. https: //doi.org/10.1016/j.foodchem.2017.12.002.

Bilková, A., H. K. Sepová, M. Bukovský, and L. Bezáková. 2011. Antibacterial potential of lactobacilli isolated from a lamb. Vet. Med. (Praha) 56:319-324. https://doi.org/10.17221/1583-VETMED.

Brazil, National Health Surveillance Agency (Ministério da Saúde, Agência Nacional de Vigilância Sanitária, Diretoria Colegiada).
2019. Lista de Padrões Microbiológicos para Alimentos. Instrução Normativa no. 60, de 23 de dezembro de 2019. (In Portuguese.)

Clark, S., and M. B. Mora García. 2017. A 100-year review: Advances in goat milk research. J. Dairy Sci. 100:10026-10044. https://doi .org/10.3168/jds.2017-13287.

de Moraes, G. M. D., R. de Abreu, A. S. Egito, H. O. Salles, L. M. F. Silva, and L. A. Nero. 2017. Functional properties of Lactobacillus mucosae strains isolated from Brazilian goat milk. Probiotics Antimicrob. Proteins 9:235-245. https://doi.org/10.1007/s12602 $-016-9244-8$

de Moraes, G. M. D., K. M. O. dos Santos, S. C. de Barcelos, S. A. Lopes, and A. S. do Egito. 2018. Potentially probiotic goat cheese produced with autochthonous adjunct culture of Lactobacillus mucosae: Microbiological, physicochemical and sensory attributes. Lebensm. Wiss. Technol. 94:57-63. https://doi.org/10.1016/j.lwt 2018.04.028.

de Oliveira, M. E. G., E. F. Garcia, E. V. de Oliveira, A. M. P. Gomes, M. E. Pintado, A. R. M. F. Madureira, M. L. da Conceição, R. C. R. E. Queiroga, and E. L. de Souza. 2014. Addition of probiotic bacteria in a semi-hard goat cheese (coalho): Survival to simulated gastrointestinal conditions and inhibitory effect against pathogenic bacteria. Food Res. Int. 64:241-247. https://doi.org/10.1016/j .foodres.2014.06.032.

de Paula, C. M., K. M. O. dos Santos, L. S. Oliveira, J. da Silva Oliveira, F. C. Alonso Buriti, and S. M. I. Saad. 2020. Fat substitution by inulin in goat milk ice cream produced with cajá (Spondias mombin) pulp and probiotic cultures: Influence on composition, texture, and acceptability among consumers of two Brazilian regions. Emir. J. Food Agric. 32:140-149. https://doi.org/10.9755/ ejfa.2020.v32.i2.2074.

de Santis, D., G. Giacinti, G. Chemello, and M. T. Frangipane. 2019 Improvement of the sensory characteristics of goat milk yogurt. J. Food Sci. 84:2289-2296. https://doi.org/10.1111/1750-3841.14692.

Escobar, M. C., M. L. Van Tassell, F. Martinez-Bustos, M. Singh, E. S. Castano-Tostado, L. Amaya-Llano, and M. J. Miller. 2012. Characterization of a Panela cheese with added probiotics and fava bean starch. J. Dairy Sci. 95:2779-2787. https://doi.org/10.3168/ jds.2011-4655.

Fabersani, E., M. V. Grande, M. V. Coll Aráoz, M. L. Zannier, S. S. Sánchez, A. Grau, R. Oliszewski, and S. M. Honoré. 2018. Metabolic effects of goat milk yogurt supplemented with yacon flour in rats on high-fat diet. J. Funct. Foods 49:447-457. https://doi.org/ 10.1016/j.jff.2018.08.042.

Fijan, S. 2014. Microorganisms with claimed probiotic properties: an overview of recent literature. Int. J. Environ. Res. Public Health 11:4745-4767. https://doi.org/10.3390/ijerph110504745.

García-Gómez, B., Á. Romero-Rodríguez, L. Vázquez-Odériz, N. Muñoz-Ferreiro, and M. Vázquez. 2019. Sensory quality and consumer acceptance of skim yoghurt produced with transglutaminase at pilot plant scale. Int. J. Dairy Technol. 72:388-394. https://doi .org/10.1111/1471-0307.12595.

Gomes, J. J. L., A. M. Duarte, A. S. M. Batista, R. M. F. de Figueiredo, E. P. de Sousa, E. L. De Souza, and R. C. R. E. Queiroga. 2013. Physicochemical and sensory properties of fermented dairy beverages made with goat's milk, cow's milk and a mixture of the two milks. Lebensm. Wiss. Technol. 54:18-24. https://doi.org/10 $.1016 / j . l w t .2013 .04 .022$.

Harte, F., L. Luedecke, B. Swanson, and G. V. Barbosa-Cánovas. 2003. Low fat set yogurt made from milk subjected to combinations of high hydrostatic pressure and thermal processing. J. Dairy Sci. 86:1074-1082. https://doi.org/10.3168/jds.S0022-0302(03)73690 $-\mathrm{X}$.

IDF (International Dairy Federation). 1995. Fermented and non-fermented milk products: Detection and enumeration of Lactobacillus acidophilus. Pages 23-25 in Fermented and Non-Fermented Milk Products. Bulletin of the IDF 306. IDF.

Jia, R., H. Chen, H. Chen, and W. Ding. 2016. Effects of fermentation with Lactobacillus rhamnosus GG on product quality and fatty acids of goat milk yogurt. J. Dairy Sci. 99:221-227. https://doi .org/10.3168/jds.2015-10114. 
Jindal, N., and J. I. S. Kattar. 2018. Microbial polysaccharides in food industry. Pages 95-123 in Biopolymers for Food Design. A. M. Grumezescu and A. M. Holban, ed. Academic Press. https://doi .org/10.1016/B978-0-12-811449-0.00004-9.

Laurent, C., P. Besancon, and B. Caporiccio. 2007. Flavonoids from a grape seed extract interact with digestive secretions and intestinal cells as assessed in an in vitro digestion/Caco-2 cell culture model. Food Chem. 100:1704-1712. https://doi.org/10.1016/j.foodchem .2005.10.016.

Lima, K. G. C., M. F. Kruger, M. T. Behrens, M. Destro, Landgraf, and B. D. Gombossy de Melo Franco. 2009. Evaluation of culture media for enumeration of Lactobacillus acidophilus, Lactobacillus casei and Bifidobacterium animalis in the presence of Lactobacillus delbrueckii subsp. bulgaricus and Streptococcus thermophilus. Lebensm. Wiss. Technol. 42:491-495. https://doi.org/10.1016/j lwt.2008.08.011.

London, L. E. E., V. Chaurin, M. A. E. Auty, M. A. Fenelon, G. F. Fitzgerald, P. R. Ross, and C. Stanton. 2015. Use of Lactobacillus mucosae DPC 6426, an exopolysaccharide-producing strain, positively influences the techno-functional properties of yoghurt. Int. Dairy J. 40:33-38. https://doi.org/10.1016/j.idairyj.2014.08.011.

Machado, T. A. D. G., M. E. G. de Oliveira, M. I. F. Campos, P. O. A. de Assis, E. L. de Souza, M. S. Madruga, M. T. B. Pacheco, M. M. E. Pintado, and R. C. R. E. Queiroga. 2017. Impact of honey on quality characteristics of goat yogurt containing probiotic Lactobacillus acidophilus. Lebensm. Wiss. Technol. 80:221-229. https: //doi.org/10.1016/j.lwt.2017.02.013.

Madureira, A. R., M. Amorim, A. M. Gomes, M. E. Pintado, and F. X. Malcata. 2011. Protective effect of whey cheese matrix on probiotic strains exposed to simulated gastrointestinal conditions. Food Res. Int. 44:465-470. https://doi.org/10.1016/j.foodres.2010 .09.010.

Martins, I. B. A., R. Deliza, K. M. O. dos Santos, E. H. M. Walter, J. M. Martins, and A. Rosenthal. 2018. Viability of probiotics in goat cheese during storage and under simulated gastrointestinal conditions. Food Bioprocess. Technol. 11:853-863. https://doi.org/10 .1007/s11947-018-2060-2.

McKevith, B., and C. Shortt. 2003. Fermented milks-Other relevant products. Pages 2383-2389 in Encyclopedia of Food Sciences and Nutrition. 2nd ed. B. Caballero, ed. Academic Press. https://doi .org/10.1016/B0-12-227055-X/00458-2

Ministry of Agriculture, Livestock, and Supply. 2000. Technical Regulation on the Identity and Quality of Goat Milk. Normative Instruction No. 37 of October 31, 2000. Accessed Dec. 14, 2021. https://pesquisa.in.gov.br/imprensa/jsp/visualiza/index.jsp?data $=08 / 11 / 2000 \&$ jornal $=1 \&$ pagina $=103 \&$ totalArquivos $=120$.

Mituniewicz-Małek, A., M. Ziarno, and I. Dmytrów. 2014. Incorporation of inulin and transglutaminase in fermented goat milk containing probiotic bacteria. J. Dairy Sci. 97:3332-3338. https://doi .org/10.3382/ps.2014-7892.

Narimatsu, A., J. R. F. Dornellas, L. M. Spadoti, P. D. Pizaia, and S. M. Roig. 2003. Avaliação da proteólise e do derretimento de queijo prato obtido por ultrafiltração (Proteolysis and melting evaluation on prato cheese obtained by ultrafiltration). Ciência e Tecnologia de Alimentos 23:177-182. (In Portuguese.) https://doi.org/10 .1590/S0101-20612003000400033.

Narvhus, J. A., and R. K. Abrahamsen. 2021. Yogurt: Role of starter culture. Pages 496-501 in Encyclopedia of Dairy Sciences, 3rd ed. P. L. H. McSweeney and J. P. McNamara, ed. Academic Press.

Pal, M., P. Dudhrejiya, and S. Pinto. 2017. Goat milk products and their significance. Beverage \& Food World 44:21-25.

Rafiq, S., N. Huma, I. Pasha, A. Sameen, O. Mukhtar, and M. I. Khan. 2016. Chemical composition, nitrogen fractions and amino acids profile of milk from different animal species. Asian-Australas. J. Anim. Sci. 29:1022-1028. https://doi.org/10.5713/ajas.15.0452.

Ramirez-Santiago, C., L. Ramos-Solis, C. Lobato-Calleros, C. PenaValdivia, E. J. Vernon-Carter, and J. Alvarez-Ramírez. 2010. Enrichment of stirred yogurt with soluble dietary fiber from Pachyrhizus erosus L. Urban: Effect on syneresis, microstructure and rheological properties. J. Food Eng. 101:229-235. https://doi .org/10.1016/j.jfoodeng.2010.06.023.
Ranadheera, C. S., C. A. Evans, M. C. Adams, and S. K. Baines. 2012. Probiotic viability and physic-chemical and sensory properties of plain and stirred fruit yoghurts made from goat's milk. Food Chem. 135:1411-1418. https://doi.org/10.1016/j.foodchem .2012.06.025.

Ribeiro, M. C. E., K. S. Chaves, C. Gebara, F. N. S. Infante, C. R. F. Grosso, and M. L. Gigante. 2014. Effect of microencapsulation of Lactobacillus acidophilus LA-5 on physicochemical, sensory and microbiological characteristics of stirred probiotic yoghurt. Food Res. Int. 66:424-431. https://doi.org/10.1016/j.foodres.2014.10 .019 .

Riener, J., F. Noci, D. A. Cronin, D. J. Morgan, and J. G. Lyng. 2010. A comparison of selected quality characteristics of yoghurts prepared from thermosonicated and conventionally heated milks. Food Chem. 119:1108-1113. https://doi.org/10.1016/j.foodchem .2009.08.025.

Roos, S., F. Karner, L. Axelsson, and H. Jonsson. 2000. Lactobacillus mucosae sp. nov., a new species with in vitro mucus-binding activity isolated from pig intestine. Int. J. Syst. Evol. Microbiol. 50:251-258. https://doi.org/10.1099/00207713-50-1-251.

Şanlıdere Aloğlu, H., and Z. Öner. 2013. The effect of treating goat's milk with transglutaminase on chemical, structural, and sensory properties of labneh. Small Rumin. Res. 109:31-37. https://doi .org/10.1016/j.smallrumres.2012.10.005.

Silanikove, N., G. Leitner, U. Merin, and C. G. Prosser. 2010. Recent advances in exploiting goat's milk: Quality, safety and production aspects. Small Rumin. Res. 89:110-124. https://doi.org/10.1016/j .smallrumres.2009.12.033.

Silva, H. L. A., C. F. Balthazar, E. A. Esmerino, R. P. C. Neto, R. S. Rocha, J. Moraes, R. N. Cavalcanti, R. M. Franco, M. I. B Tavares, J. S. Santos, D. Granato, R. G. B. Costa, M. Q. Freitas, M. C. Silva, R. S. L. Raices, S. C. Ranadheera, F. Nazzaro, A. M. Mortazavian, and A. G. Cruz. 2018. Partial substitution of $\mathrm{NaCl}$ by $\mathrm{KCl}$ and addition of flavor enhancers on probiotic Prato cheese: A study covering manufacturing, ripening and storage time. Food Chem. 248:192-200. https://doi.org/10.1016/j.foodchem.2017.12 .064 .

Terpou, A., A. Papadaki, I. K. Lappa, V. Kachrimanidou, L. A. Bosnea, and N. Kopsahelis. 2019. Probiotics in food systems: Significance and emerging strategies towards improved viability and delivery of enhanced beneficial value. Nutrients 11:1591. https:// doi.org/10.3390/nu11071591.

Verruck, S., D. Dantas, and E. S. Prudencio. 2019. Functionality of the components from goat's milk, recent advances for functional dairy products development and its implications on human health. J. Funct. Foods 52:243-257. https://doi.org/10.1016/j.jff.2018.11 .017 .

Vyhmeister, S., C. Geldsetzer-Mendoza, M. Medel-Marabolí, A. Fellenberg, E. Vargas-Bello-Pérez, and R. A. Ibáñez. 2019. Influence of using different proportions of cow and goat milk on the chemical, textural and sensory properties of Chanco-style cheese with equal composition. Lebensm. Wiss. Technol. 112:108226. https:// doi.org/10.1016/j.lwt.2019.05.124.

Wouters, R. 2012. Low fat yet rich in texture, Greek yoghurt proves irresistible to consumers. Wellness Foods Eur. 3:4-8.

Yamazi, A., T. Moreira, V. Cavicchioli, L. R. Burin, and L. A. Nero. 2013. Long cold storage influences the microbiological quality of raw goat milk. Small Rumin. Res. 113:205-210. https://doi.org/10 .1016/j.smallrumres.2013.02.004.

Yang, T., K. Wu, F. Wang, X. Liang, Q. Liu, G. Li, and Q. Li. 2014. Effect of exopolysaccharides from lactic acid bacteria on the texture and microstructure of buffalo yoghurt. Int. Dairy J. 34:252256. https://doi.org/10.1016/j.idairyj.2013.08.007.

Yildiz, H., and N. Karatas. 2018. Microbial exopolysaccharides: Resources and bioactive properties. Process Biochem. 72:41-46. https://doi.org/10.1016/j.procbio.2018.06.009.

Zhang, S. S., Z. S. Xu, L. H. Qin, and J. Kong. 2020. Low-sugar yogurt making by the co-cultivation of Lactobacillus plantarum WCFS1 with yogurt starter cultures. J. Dairy Sci. 103:3045-3054. https:// doi.org/10.3168/jds.2019-17347. 